\title{
Exploring interpreting for young children
}

\author{
Anne Birgitta Nilsen \\ Oslo and Akershus University College of Applied Sciences \\ anne-birgitta.nilsen@hioa.no
}

Research

trans-int.org

DOI: ti.105202.2013.a02

\begin{abstract}
The article presents a pilot study based on video-recordings of four experiments taking the form of encounters, each involving a Norwegian-speaking child, a woman speaking only in English and an interpreter. Taking the interpretermediated encounter as the basic research element, and applying an interactionist theoretical perspective, small children's participation in these encounters is explored. The aim of the pilot study is to use the explorations of a few children's interactions with one particular interpreter to generate hypotheses and identify new research areas that may be further investigated through a larger collection of data. Preliminary results indicate that a child as young as three has sufficient communicative competence to participate successfully in an interpreter-mediated encounter. In addition, the interpreter's simultaneous speech in the other language did not seem to disrupt a child's narrative. These findings need to be further explored through more extensive and naturally occurring data. An identified topic that needs further exploration is young children's understanding of the nature of an interpreter's specific mandate and responsibility during such interaction.
\end{abstract}

Keywords: interpreting; young children; interactionistic

\section{Introduction}

Interpreting for young children - defined in this article as children under the age of seven - is practically an unexplored field within community interpreting (Nilsen \& Hitching, 2010). While a few researchers have conducted studies on sign-language interpreting for children in schools (Hjelmervik, 2009; Schick, Williams, \& Kupermintz, 2006; Winston, 2004), to date there are still no linguistic studies on oral interpreter-mediated communication with young children. Studies focusing on older children, such as the studies on asylum-seeking minors in asylum hearings (Keselman, Cederborg, Lamb, \& Dahlström, 2008, 2010; Keselman, Cederborg, \& Linell, 2010), have been conducted, however, with results that are also relevant to interpreting for young children. These results, as well as the findings of Cecilia Wadensjö (1998, pp.185-86) in her discussion of interpreting for children, are relevant to this research, and both are discussed below.

Although most of the interpreter's assignments in the public sector involve interpreting between adults, interpreting for young children is nevertheless an important field. Interpreted events with young children take place in the public sector, such as in police interviews, childcare settings, asylum hearings and social welfare. It is important that the interpreter knows how to handle these communicative events. There is therefore a need for information regarding what to teach students of interpreting about interpreting for young children and how to train them for this purpose. Against this background, a research project was initiated at Oslo and Akershus University College of Applied Sciences. The project explores interpreting for young children through various perspectives, methods and data, with two central focuses. One focus is on young children as users of interpreters, and their communicative means of participation in interpreter- 
mediated interaction. The second focus is on strategies that can be employed in interpreting for young children. The research questions are the following:

- How do children participate and respond in interpreter-mediated dialogues?

- Which interpreting strategies are most effective in interpreting for young children?

- How do interpreter-mediated dialogues with young children differ from corresponding dialogues with adult participants?

In this article the emphasis is on the first question, namely the enquiry concerning children's participation in interpreter-mediated dialogues.

The research presented is based on a pilot study with data from videorecorded experiments and subsequent interviews with the interpreter. The theoretical perspective is interactionistic (Wadensjö, 1998), whereby the encounter as a whole is taken into consideration. Interpreting is regarded as interaction with the interpreter having two different functions, that is, both translator and mediator; a person with a position between two parties who coordinates the dialogue. Here the empirical question will focus on how four young children at different ages respond to the interpreter's translating and coordinating activities following Wadensjö's (1998) terminology. The project addresses this question through empirical examples of children's interactions with an interpreter and through their responses to the interpreter's turntaking. In this manner, the discussion will not only explore the children's responses but will also illuminate how, and the extent to which, interpreters may intervene successfully during interaction with young children.

The aim of the pilot study, with its very limited amount of data, is of course not to give definite answers as to how children in general respond and participate in interpreter-mediated dialogues. Rather the aim is to use the explorations of a few children's interactions with one particular interpreter to generate hypotheses and identify new research areas that may be further investigated through a larger collection of data.

The following paragraphs first provide a description of the methodology. Thereafter, the article presents and discusses some of the results. Finally, the article draws a conclusion from the pilot study and makes proposals for further investigation within this new field of research.

\section{The experiments}

In these experiments, young Norwegian-speaking children were placed in interpreter-mediated dialogues. In these settings, they were instructed to talk with a person whose language, English, they did not understand, as shown in the still photo below from one of the video recordings of an experiment with a girl of four-and-a-half.

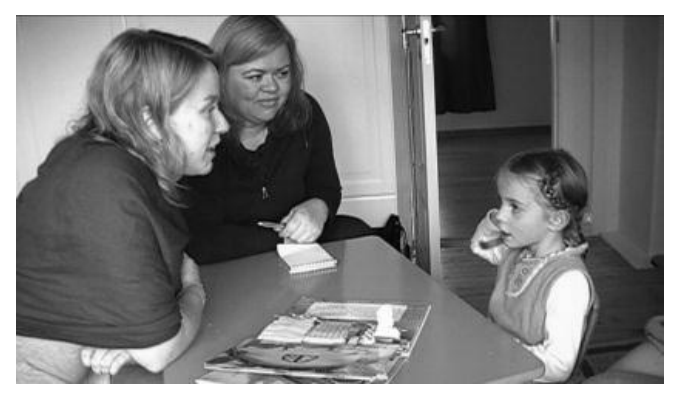


The adult participants have given their written consent for the images and their names used in publications associated with research. The children's parents have given their consent to the still photos of the children used, and that their first names are used.

The interpreter selected for the experiments, the woman with a pen and a notebook, complies with the Norwegian ethical guidelines for interpreters (IMDI, 1997). She holds a bachelor's degree in interpreting, and is a Norwegian state-authorised interpreter from Spanish and English with many years' experience of interpreting in the public sector in Norway. She has some earlier experience of interpreting for young children, but her experience has mainly been with interpreting for adults. The children's English-speaking dialogue partner selected for the experiments is a professional interpreter and experienced user of interpreters. Her being an experienced interpreter user and her general understanding of interpreter-mediated communication was crucial for these experiments, as she would function as a communicative role model for the children - a role model from whom they could learn how to handle this particular form of communication.

Before the experiments, the children were told that they were going to talk to a woman called Hilde, who spoke English, and that the interpreter, Berit, would help them talk to Hilde, and help them to understand what Hilde said. They were also told the reason for the experiment: that the author as a researcher and teacher of interpreting was interested in learning about children's participation in interpreter-mediated dialogues. They were not told that Hilde speaks and understands Norwegian as well as English, but for ethical reasons they would have been told if they had asked, in order not to confuse them by arousing doubts about what was going on in the interaction.

The author introduced the children to their dialogue partner, Hilde Fiva, and the interpreter, Berit Nordhuus. After the introduction the author turned the two cameras on, one camera focusing on the child, and the other focusing on the interpreter. This set up was designed to enable the study and transcription of both the child's and the interpreter's communicative actions in detail. Hilde started the dialogue with the child by explaining what she wanted to talk about. The topics of the dialogues were selected in advance, since the aim of the recordings was to elicit as much interaction and participation in the dialogues as possible. Topics were chosen that, it was assumed, would attract the child's interest and in turn facilitate interaction and participation.

\section{The participating children and the setting of the experimental sessions}

The experiments were conducted in four sessions with four different children: three girls, a six-and-a-half year-old and two four-and-a-half year-olds, and a boy who had just turned three at the time of the experiment. Two of the children were the author's own daughters, Sara, six-and-a-half, and Lotte, four-and-a-half. The author chose her own daughters for two reasons. First, as the author knows them well, motivating them to participate was unlikely to represent an obstacle. In fact they were excited about the event and were looking forward to the session. The author also chose her own children because she could easily introduce them to strangers whom they had not met before, that is, the interpreter and their dialogue partner, and create a social environment where they would feel comfortable and interact as normally as possible without being inhibited by insecurity. For this reason one of Lotte's girlfriends, Marie, whom the author also knows well, was also selected to participate. Another advantage with Marie was that she is for the most part 
outgoing and very interested in making new friends. The three-year-old boy was accompanied by his mother, who is one of the author's colleagues at Oslo and Akershus University College of Applied Sciences. Like Marie, the boy is very outgoing and interested in communication.

The experiment was set up in a way intended to cause as little stress as possible for the children. For the same reason, the sessions with the three girls were conducted in Sara's and Lotte's own bedrooms, rooms that were also well known to Marie. The session with the three-year-old boy was conducted in the author's office with his mother present in the room, but outside the range of the camera. In in-experimental situations, trying to get someone known by or familiar to children is often not possible, and the establishment of trust is of course in turn more challenging than in our experiments. In that manner the experiments therefore differ from realistic situations such as for example police interviews where children may be placed on their own with two strangers. However it would not be ethically appropriate to subject children to stress and insecurity for the purpose of research. Furthermore the study focuses on the communicative rather than psychological aspects of interpreting for children, and by setting up these experiments we were to a large degree able to isolate the communicative factors.

Assuming that older children with greater general communicative competence and abilities would more likely be able to participate in interpreter-mediated dialogues, the first session was conducted with Sara, sixand-a-half years old. Sara is bilingual Dutch-Norwegian and this was not her first experience with interpreting. Her parents had previously interpreted for her, between English and Dutch, as well as between Arabic and Norwegian while on holiday in Egypt. She has also interpreted herself in family settings in the Netherlands for her younger sister, whose Dutch was weaker. Nonetheless, this was the first time that she was on her own with a person whose language she did not understand and a professional interpreter, in a setting arranged in the triangle typical for public-sector interactions, such as police interviews with children, as shown in the photo below:

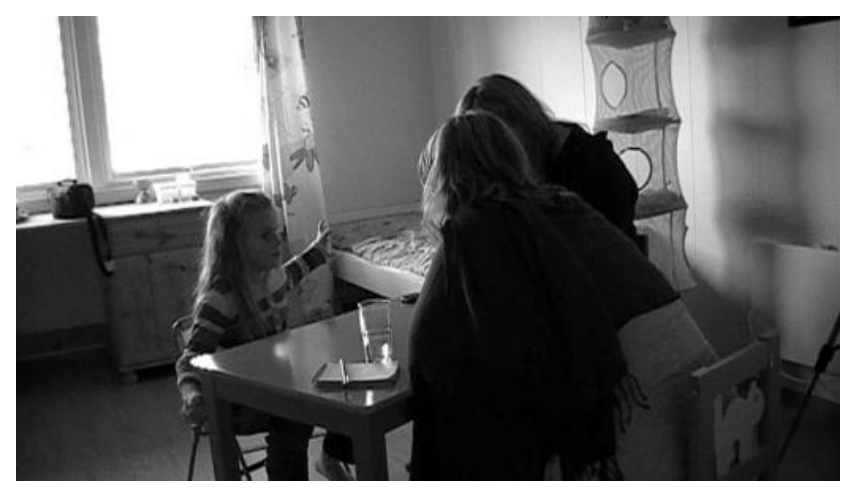

Sara's earlier experiences with interpretation had been of much shorter duration, where she had been asked her name and other simple questions with short answers. These experiences are nonetheless worth mentioning, because they indicate that she has an understanding of what interpreter-mediated communication involves. Furthermore she has an understanding of the fact that people speak different languages, an understanding with a strong basis in her own bilingualism. In that manner she may be representative of many of the children with minority linguistic backgrounds in Norway whom interpreters may meet in the public sector. Many of these children are also more or less bilingual, and they have an understanding of the fact that people may speak different languages. They probably also have similar previous 
experiences with interpreting. The experiment with Sara may therefore indicate what we can expect from a communicative point of view in interpreter-mediated communication with children her age. Psychologically however, she may not be representative, because the children that interpreters meet in public-sector settings such as police interviews are often children with psychological disturbances, such as trauma. Nonetheless, since this study as earlier mentioned focuses on the communicative rather than psychological aspects of interpreting for children, these factors are not considered relevant in this setting.

Lotte, four-and-a-half years old, is bilingual like her sister, Sara, and has many of the same experiences, but fewer due to her being two years younger. Marie, four-and-a-half years old, is monolingual. She does, however, have an understanding that people speak different languages, as she has spent much time with Lotte and her father. Lotte's father always speaks Dutch to Lotte, but of course speaks Norwegian to Marie. The author has interpreted for Marie in that context, for example during meals. Mikkel, three years old, is monolingual, but has had experiences with people speaking different languages. This experiment was, however, also his first experience with an interpreter-mediated dialogue.

The session with Sara was, as already mentioned, conducted in her bedroom, where the interpreter, Berit, the English-speaking woman, Hilde, and Sara were seated on low children's chairs at a low table. Sara was seated opposite Hilde, and the interpreter sat to Sara's left and to Hilde's right-hand side. The author, Sara's mother, sat on the floor next to Sara, on her right side, at the beginning of the dialogue, and moved to the back of the room as Sara became more comfortable with Hilde and the interpreter.

The sessions with Lotte and Marie were conducted in the same way, in a similar setting in Lotte's bedroom, on children's chairs at a low table, as illustrated in the still photo below where the author is seated at the back:

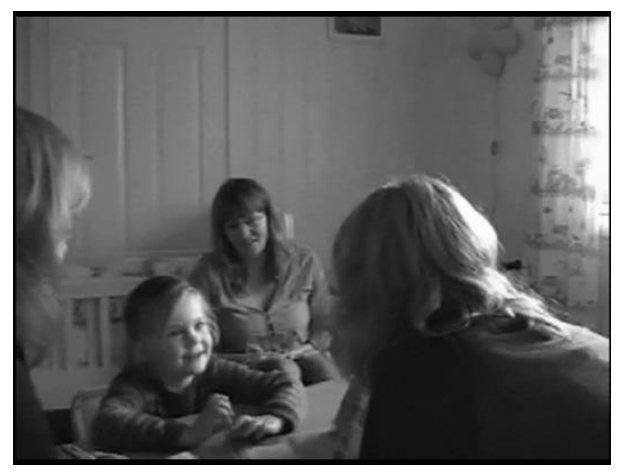

The session with the three-year-old boy, Mikkel, was also conducted in the same way with children's table and chairs, but as mentioned in the author's office with his mother present.

\section{Methods of analysis}

The theoretical framework for this research was inspired by Cecilia Wadensjö's interactionistic approach, where the encounter as a whole is taken into consideration. In this approach, interpreting is regarded as interaction, with the interpreter having two different functions, as a translator and a mediator: a person with a position between two parties who coordinates the dialogue. In theory, translating and mediating may be distinguishable activities, but in practice they are intimately intertwined (Wadensjö, 1998, 
p.7). As already noted, the empirical question will focus on how young children at different ages interact with the interpreter and respond to the interpreter's translating and coordinating activities (Wadensjö, 1998). More specifically the coordinating activities in this article are limited to an example of the interpreter's managing of turn-taking, that is, when she is taking a turn to interpret. This example is interesting because it is an example where a child is being interrupted in her speech, but where the interruption does not seem to hinder the flow of communication.

The experiment's focus on how the children respond to the interpreter's translating activities addresses the children's understanding of this role in general. Do the children accept and understand that the interpreter is not a primary participant in the dialogues but merely has the function of rendering the other participant's speech?

The analyses are based on the framework of conversation analysis (CA), which is an approach to the study of natural conversation used to obtain insight into the ways in which people interact (Sacks, Schegloff, \& Jefferson, 1974). The goal of conversation analysis is the description and explication of competences that ordinary speakers use and rely on when participating in socially organised interaction. In this case, the relevant interaction is interpreter-mediated communication with young children.

The data collected consist of four video-recorded interpreter-mediated dialogues. A transcription was made from the video recordings based on the system developed by Harvey Sacks, Emanuel A. Schegloff and Gail Jefferson (1974).

In the transcriptions, the following symbols are used:

Cursive: Author's translation of speech

, : Continuing intonation unit

$\therefore$ Final intonation unit

?: Appeal

[ ]: overlapping with speech above

Stress: underlining indicates emphasis

Analyses from the transcriptions are presented below, focusing on the children's interactions with the interpreter and the children's responses to the interpreter's coordinating role in turn-taking.

\section{Interaction with the interpreter}

As noted, the children were prepared for the interpreter's translating role before the sessions took place. They were told that Berit was there in order to help them understand what Hilde said and to help Hilde understand them. The children nevertheless responded in rather different ways to this role.

Sara participated in the dialogue for forty-two minutes. During the dialogue she gradually seemed to adopt a view of the interpreter as her actual dialogue partner and not as a mere translator. At the beginning of the dialogue she sat with her legs under the table directly opposite Hilde, but as the dialogue developed she moved her body progressively towards the interpreter. During the interaction, Sara turned her attention increasingly towards the interpreter and away from the primary interlocutor, Hilde. She progressively reduced her eye contact with Hilde and increased eye contact with the interpreter. By the end of the dialogue she had turned her body in such a way that she sat with her knees and face towards the interpreter, so that her right shoulder was pointing towards Hilde. This shift in position may 
indicate that Sara had a view of the interpreter as her actual dialogue partner, as she paid less attention to Hilde, and as can be viewed in the photos below.
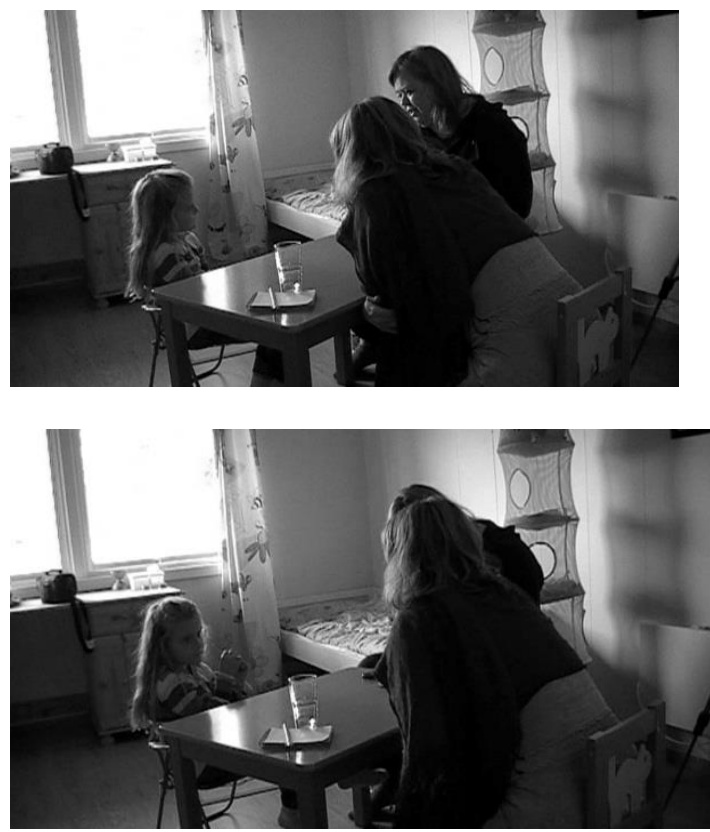

The response of Mikkel, the three-year-old boy, differs from Sara's, as he was still seated towards Hilde at the end of the dialogue, as illustrated in the stills below where only the interpreter's hands are visible. However both children looked at the interpreter and established eye contact with her when she talked, and with Hilde when she talked.
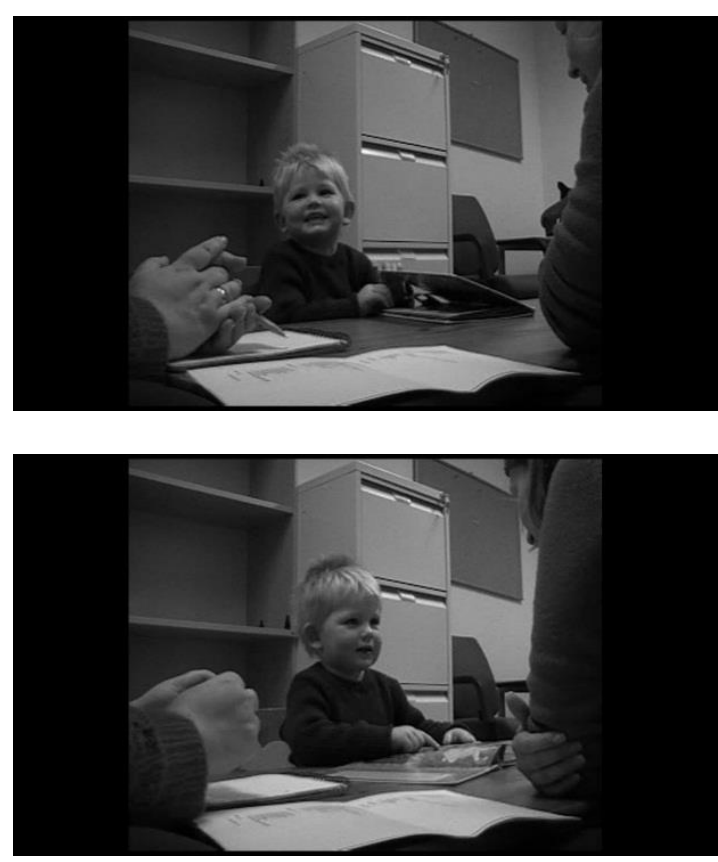

The interpreter-mediated dialogue with Mikkel lasted for seventeen minutes, and was closed when he lost interest in the dialogue and left the table. As can be seen in the still photos from the video recording, both children shift between looking at Hilde and the interpreter according to who is speaking. It is, however, interesting to notice that also the boy seems to address his answers to the interpreter, rather than to the primary speaker, Hilde. This 
indicates that Mikkel may not have fully understood the difference between the primary speaker and the interpreter, and also that he may not have had a clear understanding of the interpreter's role as translator. Mikkel's lack of understanding of the interpreter's role as translator did not, however, seem to hinder the communication, although it may certainly raise ethical concerns. Mikkel not being hindered in communication is illustrated in the example below where he has been participating in the interpreter mediated dialogue for approximately eight minutes when the example starts:

\begin{tabular}{|c|c|c|c|}
\hline Speaker & $\begin{array}{l}\text { Verbal turn-taking } \\
\text { sequence }\end{array}$ & Translation & $\begin{array}{l}\text { Description of } \\
\text { the non-verbal }\end{array}$ \\
\hline Hilde & $\begin{array}{l}\text { tell me something mikkel, } \\
\text { what do you think is inside } \\
\text { here? }\end{array}$ & & $\begin{array}{l}\text { Mikkel looks at } \\
\text { Hilde. } \\
\text { Hilde looks at } \\
\text { Mikkel. } \\
\text { Hilde points at } \\
\text { her pregnant } \\
\text { belly. }\end{array}$ \\
\hline Interpreter & $\begin{array}{l}\text { fortell meg en ting mi } \\
\text { mikkel, hva tror du det er } \\
\text { inni her? }\end{array}$ & $\begin{array}{l}\text { tell me something } \\
\text { mi mikkel, what } \\
\text { do you think it is } \\
\text { inside here? }\end{array}$ & $\begin{array}{l}\text { Interpreter looks } \\
\text { at Mikkel and } \\
\text { points at Hildes } \\
\text { belly. }\end{array}$ \\
\hline Mikkel & & & $\begin{array}{l}\text { Mikkel plays } \\
\text { with the book. }\end{array}$ \\
\hline Hilde & $\begin{array}{l}\text { what do you think is inside } \\
\text { here? }\end{array}$ & & $\begin{array}{l}\text { Hilde looks at } \\
\text { Mikkel. } \\
\text { Mikkel plays } \\
\text { with the book. }\end{array}$ \\
\hline Interpreter & $\begin{array}{l}\text { hva tror du er som er inni } \\
\text { her'a? }\end{array}$ & $\begin{array}{l}\text { what do you think } \\
\text { it is that is inside } \\
\text { here? }\end{array}$ & $\begin{array}{l}\text { Interpreter looks } \\
\text { at Mikkel. } \\
\text { Mikkel plays } \\
\text { with the book. }\end{array}$ \\
\hline Mikkel & & & $\begin{array}{l}\text { Mikkel takes a } \\
\text { quick look at } \\
\text { interpreter, then } \\
\text { puts his face on } \\
\text { the table and } \\
\text { looks at his } \\
\text { mother at the } \\
\text { other side of the } \\
\text { room. }\end{array}$ \\
\hline Hilde & do you think it's a bear? & & $\begin{array}{l}\text { Hilde looks at } \\
\text { Mikkel. } \\
\text { Mikkel has his } \\
\text { face on the table } \\
\text { and looks away } \\
\text { from the } \\
\text { dialogue. }\end{array}$ \\
\hline Mikkel & & & $\begin{array}{l}\text { Mikkel lifts his } \\
\text { face up from the } \\
\text { table and looks at } \\
\text { Hilde. }\end{array}$ \\
\hline Interpreter & tror du det er en bjørn? & $\begin{array}{l}\text { do you think it's a } \\
\text { bear? }\end{array}$ & $\begin{array}{l}\text { Mikkel looks at } \\
\text { Hilde. }\end{array}$ \\
\hline Mikkel & nei & no & Mikkel looks \\
\hline
\end{tabular}




\begin{tabular}{|l|l|l|l|}
\hline & & & down. \\
\hline Hilde & maybe it's aaa a rabbit? & & $\begin{array}{l}\text { Mikkel looks up } \\
\text { at Hilde. }\end{array}$ \\
\hline Interpreter & kanskje det er en kanin? & $\begin{array}{l}\text { maybe it's a } \\
\text { rabbit? }\end{array}$ & $\begin{array}{l}\text { Mikkel turns } \\
\text { towards the } \\
\text { interpreter. }\end{array}$ \\
\hline Mikkel & ikke en kanin & not a rabbit & $\begin{array}{l}\text { Mikkel smiles. } \\
\text { Mikkel looks at } \\
\text { interpreter. }\end{array}$ \\
\hline Interpreter & not a rabbit & $\begin{array}{l}\text { Interpreter } \\
\text { smiles. } \\
\text { Interpreter looks } \\
\text { at Hilde. }\end{array}$ \\
\hline Hilde & oh, what could it be then? & & $\begin{array}{l}\text { Mikkel turns } \\
\text { towards Hilde. }\end{array}$ \\
\hline Interpreter & men hva kan det være for & noe da, da? & but what could it \\
be then? & $\begin{array}{l}\text { Interpreter looks } \\
\text { at Mikkel. } \\
\text { Mikkel turns } \\
\text { towards } \\
\text { interpreter }\end{array}$ \\
\hline Mikkel & en mikkel & $\begin{array}{l}\text { Mikkel looks at } \\
\text { interpreter. }\end{array}$ \\
\hline Interpreter & a mikkel & $\begin{array}{l}\text { Interpreter looks } \\
\text { at Hilde. }\end{array}$ \\
\hline
\end{tabular}

The behaviour of the two four-year-old girls was similar to Mikkel's: they too, remained as they were originally seated with their bodies directed towards Hilde, and seemed also to communicate with her. The book that can be seen on the table in the still photo above may explain why the three younger children seemed to be less focused on the interpreter and interacted more with their dialogue partner. In each of the sessions, the book was kept between the child and Hilde and the dialogue was based on pictures in the book. In this manner the book may have contributed to keeping the child's attention directed towards Hilde. In particular, the interlocutors engaged in non-verbal communication that was not dependent on the interpreter, such as pointing at pictures and turning the pages of the book. This non-verbal communication seemed to establish contact and a relationship between the primary interlocutors, as well as keeping the child's focus on his or her dialogue partner. In the dialogue with Sara, the six-year-old, there were no such books or other items that could trigger non-verbal communication and establish contact between Sara and Hilde.

The differences in the progression of the dialogues with the children indicates that it may be easier for users of interpreters to establish contact with a child and keep its attention by establishing non-verbal communication based on a book or another item that they can share in the dialogue. On the other hand it is evident in these recordings that the interpreter attracts the child's interest by making eye-contact, and in this way establishes a relationship, since gaze can be understood as a demand to interact (van Leeuwen \& Jewitt, 2001, p.31) in this context. Jewitt and van Leeuwen state that gaze demands something from the viewer, demands that the viewer enter into some kind of relation with the person who is gazing at them. By combining her gaze with smiles - as she often did in this dialogue - the interpreter asks the child to enter into a relation of social affinity. In a discussion on this matter after the experiment, the interpreter said that the situation represented a difficult dilemma for her. She was of course aware of 
the fact that she drew too much of the child's attention with her gaze, but on the other hand she was worried that the strategy she would use for adults in such instances, that is, withdrawal of eye contact, would cause the child to feel rejected. Such an effect on the child could further affect the progress of the dialogue in a negative way, and represent a practical problem, but could also cause an ethical problem for the interpreter, as it could lead to an unpleasant feeling of rejection for the child that the interpreter in turn would be responsible for.

The experiments were intended to answer the question whether young children under the age of seven accept and adapt to an interpreter's translating and coordinating roles. The question concerning the interpreter's translating role relates to the children's understanding of who they are actually engaging in dialogues with, whether they accept and adapt to the person they are supposed to address, and how they view the interpreter's role as a translator. To what extent do the children understand that the interpreter is only rendering what the other person says in another language? The question is impossible to answer definitively. Nonetheless, the fact that Sara developed a much stronger involvement with the interpreter than did the other children may indicate that she had a stronger perception than did the other children of interacting with the interpreter rather than with her dialogue partner, Hilde.

The limits of the interpreter's coordinating role are not clear. As illustrated in the dialogues, these unclear limits represent a challenge both for the interpreter as well as for the professional interpreter user. The challenge for the professional interpreter user is to keep the child's attention and focus, to maintain non-verbal contact with the child. The challenge for the interpreter is the opposite, that is, to avoid attracting too much attention. A Norwegian policewoman specialising in interviewing young children put it this way in an interview with the author: 'It is important that the interpreter is pleasant and friendly when interpreting for young children, but she should not be more pleasant and friendly than me.' The statement is interesting because it addresses a new focus within community interpreting, namely the nonverbal communication between the interlocutors who are not able to communicate verbally but who share a clear need for establishing contact non-verbally. Interpreter-mediated communication is therefore not only a matter of communication through an interpreter, as is often presumed. In order for this communication to function optimally the primary interlocutors must also establish direct non-verbal contact.

The challenge for the interpreter is to help establish and maintain the child's trust and interest in the communicative event, without excluding the other interpreter user and taking over her role as participant. Finding this balance may be particularly challenging in dialogues with children, and probably especially with young children due to their vulnerability and lack of experience communicating with strangers. This question of balance raises a communicative phenomenon that Erving Goffman (1971) identifies as 'facework', which has also been discussed in the context of interpreter-mediated communication by Wadensjö (1998, pp.166-57). Face-work, in Goffman's definition, is behaviour that serves to counteract communicative incidents that threaten face, or self-esteem. Face-work is performed to avoid the risk of hurting others' feelings with disrespectful behaviour and consequent loss of self-respect, as may occur when the interpreter withdraws her non-verbal contact with the child and the child in turn feels rejected. Wadensjö's examples from interpreting for children in healthcare settings - in which a similar case is described - are also relevant for our research. Wadensjö states that even when the interpreter remained principally 'the interpreter', 
occasionally she distanced herself from this role and came across rather in the role of 'kind lady'. As a result, the interpreter clearly established a closer relationship with the child than did the assistant nurse (Wadensjö, 1998, pp.186-87). Wadensjö's examples strengthen our observation that this is a field with a demand for more knowledge.

Let us turn to the question of the children's understanding of the interpreter's coordinating function.

\section{Responses to the interpreter's coordinating role}

The discussion of the interpreter's turn-taking has been of interest to several scholars (see for example Frøili, 2001; Hatim \& Mason, 1990; Roy, 2000). This article addresses how interpreters may intervene successfully during interaction. In Jorun Frøili's words, successful intervention depends on the interpreter's ability to choose the right moment to grab the floor, in other words, timing (Frøili, 2001, p.136). In Sacks, Schegloff and Jefferson's (1974) terminology this moment can be described as a transition relevance place. The example presented below is interesting because it involves the interpreter interrupting a young child in order to interpret. It is of course interesting to see how the interpreter alters the volume of her voice and speed of her speech, as indicated in the transcription below. But more interesting are the child's responses to the interruptions. In this following passage Sara is being interrupted by the interpreter, as shown in the transcription below where Sara is in the middle of explaining a game that she plays with her friends during recess at school.

\begin{tabular}{|c|c|c|c|}
\hline Speaker & $\begin{array}{l}\text { Verbal turn-taking } \\
\text { sequence }\end{array}$ & Translation & $\begin{array}{l}\text { Description of } \\
\text { the non-verbal }\end{array}$ \\
\hline 1.Hilde & $\begin{array}{l}\text { okay, } \\
\text { what happens when that } \\
\text { when the person from } \\
\text { chocolate land catches } \\
\text { the stick? } \\
\text { what do they do then? }\end{array}$ & & $\begin{array}{l}\text { Sara looks at } \\
\text { Hilde. } \\
\text { Hilde looks at } \\
\text { Sara. }\end{array}$ \\
\hline 2.Interpreter & $\begin{array}{l}\text { okay, men hva er det } \\
\text { som skjer da når den } \\
\text { personen fra } \\
\text { sjokoladeland får tak i } \\
\text { pinnen? } \\
\text { hva er det som, } \\
\text { hva gjør de da? }\end{array}$ & $\begin{array}{l}\text { okay but what } \\
\text { happens when the } \\
\text { person from } \\
\text { chocolate land } \\
\text { catches the stick? } \\
\text { what is that, } \\
\text { what do they do then? }\end{array}$ & $\begin{array}{l}\text { Sara turns head } \\
\text { towards } \\
\text { interpreter. Sara } \\
\text { and interpreter } \\
\text { look at each } \\
\text { other } \\
\text { throughout } \\
\text { sequence. }\end{array}$ \\
\hline 3.Sara & $\begin{array}{l}\text { da må man, } \\
\text { da skal man løpe, } \\
\text { og så skal man hoppe, } \\
\text { og så er det mange som } \\
\text { står sånn }\end{array}$ & $\begin{array}{l}\text { then one has to, } \\
\text { then one has to run } \\
\text { and then one must } \\
\text { jump, } \\
\text { and then there are } \\
\text { many who stand like } \\
\text { this }\end{array}$ & $\begin{array}{l}\text { Sara and } \\
\text { interpreter: eye- } \\
\text { contact } \\
\text { throughout } \\
\text { sequence. } \\
\text { Sara holds her } \\
\text { arms in front of } \\
\text { her chest and } \\
\text { makes a circle }\end{array}$ \\
\hline
\end{tabular}




\begin{tabular}{|c|c|c|c|}
\hline & også & and then & \\
\hline 4.Interpreter & $\begin{array}{l}\text { [and] then we have to } \\
\text { run }\end{array}$ & & \\
\hline 5.Sara & $\begin{array}{l}\text { [også] } \\
\text { Også }\end{array}$ & $\begin{array}{l}\text { and then } \\
\text { and then }\end{array}$ & $\begin{array}{l}\text { Sara and } \\
\text { interpreter: eye- } \\
\text { contact } \\
\text { throughout } \\
\text { sequence. }\end{array}$ \\
\hline 6.Interpreter & $\begin{array}{l}\text { [and] hold his hands } \\
\text { like this. }\end{array}$ & & $\begin{array}{l}\text { Interpreter } \\
\text { holds her arms } \\
\text { in front of her } \\
\text { chest and makes } \\
\text { a circle. } \\
\text { Interpreter } \\
\text { speaks very } \\
\text { fast. Interpreter } \\
\text { looks at Hilde }\end{array}$ \\
\hline 7.Sara & $\begin{array}{l}\text { [også skal] den hoppe } \\
\text { to eller tre ganger, }\end{array}$ & $\begin{array}{l}\text { and then you have to } \\
\text { jump two or three } \\
\text { times }\end{array}$ & $\begin{array}{l}\text { Sara and } \\
\text { interpreter: eye- } \\
\text { contact } \\
\text { throughout } \\
\text { sequence. } \\
\end{array}$ \\
\hline 8.Interpreter & $\begin{array}{l}\text { then you have to jump } \\
\text { two or three times, }\end{array}$ & & $\begin{array}{l}\text { Interpreter } \\
\text { speaks fast and } \\
\text { keeps eye- } \\
\text { contact with } \\
\text { Sara. } \\
\end{array}$ \\
\hline 9.Sara & [også] skal & and then & \\
\hline 10.Hilde & [with the stick?] & & \\
\hline 11.Interpreter & med pinnen? & with the stick? & $\begin{array}{l}\text { Interpreter } \\
\text { speaks with } \\
\text { very low } \\
\text { volume and } \\
\text { looks at Sara. }\end{array}$ \\
\hline 12.Sara & $\begin{array}{l}\text { [også skal man] spytte, } \\
\text { også skal man spytte, } \\
\text { og så skal man prøve å } \\
\text { kaste pinnen, imellom } \\
\text { hullet. }\end{array}$ & $\begin{array}{l}\text { and then one has to } \\
\text { spit } \\
\text { and then one has to } \\
\text { spit, } \\
\text { and then one has to } \\
\text { try and throw the } \\
\text { stick, } \\
\text { in between the hole }\end{array}$ & $\begin{array}{l}\text { Sara bends her } \\
\text { arm and lifts it. } \\
\text { Sara holds her } \\
\text { arms in front of } \\
\text { her and makes a } \\
\text { circle. } \\
\text { Sara looks at } \\
\text { interpreter } \\
\text { throughout } \\
\text { sequence. }\end{array}$ \\
\hline 13.Interpreter & $\begin{array}{l}\text { and then they have to } \\
\text { spit, } \\
\text { and then they have to } \\
\text { try and throw the stick } \\
\text { in between the hole. }\end{array}$ & & $\begin{array}{l}\text { Interpreter } \\
\text { looks at Hilde. }\end{array}$ \\
\hline
\end{tabular}


As the transcription shows, Sara's speech is not noticeably disturbed by the interpreter's intervention and the overlapping speech. The child struggles for her turn, and continues her description of the game when she is again given her turn to speak. She does not lose track of her narration. This is an interesting example, because much literature on professional monolingual dialogues with children recommends that the adult should not interrupt the child because it may lead to their losing track of their narrative. This recommendation, which concerns many interpreters, may be a hindrance in interpreter-mediated dialogues with children. In fact this concern is one of the reasons why many interpreters are reluctant to interpret for young children.

As mentioned earlier, it is also interesting to note the interpreter's use of voice volume and speed in this passage. For example, the interpreter lowers her voice when interpreting Hilde as Hilde interrupts Sara in line 10. This 'contextualisation cue' (Gumperz, 1982) renders the interpreter's voice less insistent, so that the child may perceive it as something that she does not have to respond to. This seems to be the case here, as Sara continues her description of the game that she plays during recess at school, ignoring the interpreter's question. This passage may therefore be described as an instance of the child being empowered by the interpreter. Seen in that light, the example illustrates Birgitte Englund Dimitrova's discussion of the interpreter's responsibility in the interaction process (Dimitrova, 1997). Englund Dimitrova asks what the interpreter should do when the two parties in a dialogue compete for the floor. Which party should the interpreter choose to interpret for? Amongst our informants, the answer is in favour of the weaker party, meaning the party with less power in the communicative event, the child. Further research on this question would be interesting, as a different study has described examples of the opposite phenomenon, namely where minors are disempowered by the interpreter (Keselman, Cederborg, \& Linell, 2010).

In the dialogues with the four-year-old girls, Lotte and Marie, and the boy of three, there were no examples of the interpreter taking a turn to interpret within a longer passage of speech. This is likely due to the fact that these children, as with most children of their age, spoke in shorter passages than did Sara. Such shorter passages of speech do not represent a challenge for the interpreter's memory. In the dialogue with Marie, however, there is an interesting example of the interpreter interpreting in simultaneous mode while Marie is naming the different toys she has in her dollhouse. The interpreter does the simultaneous interpreting in a very low voice in order not to disturb Marie in her litany.

The answer to the question of how the children adapted to the interpreter's coordinating role seems clear-cut as regards the coordination of turn-taking. None of the children seemed to have any difficulties adapting to the interpreter's coordinating role in this respect. They all seemed to accept the interpreter's coordination of the turn-taking - this particular communicative 'pas de trois' in the terms of Cecilia Wadensjö (1998, p.12) in the dialogues. The children's turn-taking competence, as previously developed for monolingual communication, therefore appears to have been applicable and sufficient for interpreter-mediated communication. This answer is however only indicative, as the very limited data from this pilot study are insufficient to derive definitive answers concerning children's competence in general. More definitive answers would have to be based on a larger amount of data gathered from sessions with a larger number of participating children. Our results are therefore mainly interesting as a hypothesis that may be explored in further research: 
- Children as young as three may be able to participate in interpretermediated communication.

A particularly interesting passage from one of the dialogues occurred when the interpreter interrupted a six-year-old in order to interpret what she was saying for the other participant. The passage is interesting because the girl did not seem distracted, but rather continued her narrative. This instance may indicate that an interpreter's interruptions differ from interruptions in monolingual dialogues, since the interruptions are in a language the child does not understand, and are therefore more comparable to other types of meaningless noise. Of course, as with adults, the interpreter should be careful as to when and how often to interrupt a child. That said, this example forms the basis for a new hypothesis:

- The interpreter's interruptions differ from communicative interruptions in monolingual dialogues, and may be less likely to cause the child to lose track of narrative.

The hypothesis may be further explored with larger amounts of data from realistic interpreter-mediated dialogues with young children in the public sector.

\section{Conclusion}

This article has presented examples of children's interaction with an interpreter. One of our first questions concerned children's abilities to participate in interpreter-mediated communication. Are they really able to participate? This is a question mainly about the turn-taking system in these dialogues. Do the children adapt to this system in which the interpreter also has her turn to talk?

The experimental dialogues were successful in the sense that both parties - the adult and the child - participated, and the interpreter managed to translate the content of the dialogue from one party to the other. Even Marie and Mikkel, the two young children with very limited bilingual experiences, participated and contributed to the dialogues. Their participation indicates that their monolingual turn-taking competence was sufficient for interpretermediated communication, and sets the ground for new hypotheses.

The article has also shown that it seems important to arrange for nonverbal communication between the primary interlocutors, so that the child is not left with the understanding that she is talking principally to the interpreter. This is however not a feature that distinguishes interpretermediated communication with young children from interpreter-mediated communication with adults, but is a rather well-known challenge in general. Nonetheless, this particular issue may present a greater challenge when interpreting for children because the interpreter must balance the need to ensure that the child understands that she is talking principally with her dialogue partner with the need to pay sufficient attention to the child - for example by meeting the child's demand for contact through gaze - to avoid causing the child to feel rejected by the person who speaks her language. It is therefore imperative that the professional adult interpreter-user - the child's dialogue partner - has strategies for attracting and maintaining the child's attention, since children, like adults who are inexperienced interpreter-users, are likely to direct their attention towards the person speaking and 
understanding their language. The example leads the way to a new field of research concerning the interpreter user. A central question in this field is: How can the interpreter user establish and maintain contact with young children solely through means of non-verbal communication?

Interpreting for children does not seem to differ substantially from the question of interpreting for adults, since children seem to participate and respond in interpreter-mediated communication in ways similar to adults. The challenge for the community interpreter therefore appears to be much the same as in dialogues with adults: not to attract too much attention, but to attract enough to establish trust. Intervening, as in taking turns, also seems possible when interpreting for children, but as with adults requires effective strategies. Nonetheless, due to the limited amount of data derived from this pilot study, the above answers are only suggestive at this stage and need to be further explored through more extensive data. 


\section{References}

Dimitrova, B. (1997). Degree of Interpreter Responsibility in the Interaction Process. In S. Carr, R. Roberts, A. Dufour \& D. Steyn (Eds.), The Critical Link: Interpreters in the Community (pp. 147-164). Amsterdam: Benjamins.

Frøili, J. (2001). Signals at the transition place: The interpreter's turn-taking in dialogues. In A. Hvenekilde \& J. Nortier (Eds.), Meetings at the Crossroads. Studies of multilingualism and multiculturalism in Oslo and Utrecht (pp.136-157). Oslo: Novus forlag.

Goffman, E. (1971). The presentation of self in everyday life. Harmondsworth: Penguin Books.

Gumperz, J. (1982). Discourse strategies. New York: Cambridge University Press.

Hatim, B., \& Mason, I. (1990). Discourse and the translator. Harlow: Longman.

Hjelmervik, E. (2009). Tolking for barn i skolen (Interpreting for children in school). In A. L. Hansen, N. Garm \& E. Hjelmervik (Eds.), Hørsel språk og kommunikasjon: en artikkelsamling (pp. 91-99). Levanger: Kompetansesenteret.

IMDI. (1997). Retningslinjer for god tolkeskikk. Tolkeetiske retningslinjer (Ethical guidelines for interpreters). Retrieved from http://www.tolkeportalen.no/tolkeportalen/templates/CommonPage 7145.aspx

Keselman, O., Cederborg, A., Lamb, M., \& Dahlström, Ö. (2008). Mediated communication with minors in asylum-seeking hearings. Journal of Refugee Studies, 21(1), 103-116.

Keselman, O., Cederborg, A., Lamb, Michael E., \& Dahlström, Ö. (2010). Asylum seeking minors in interpreter-mediated interviews: What do they say and what happens to their responses? Journal of Child \& Family Social Work, 21(1), 103-116.

Keselman, O., Cederborg, A., \& Linell, P. (2010). 'That is not necessary for you to know!' Negotiation of participation status of unaccompanied children in interpretermediated asylum hearings. Interpreting, 12(1), 83104.

Nilsen, A., \& Hitching, T. (2010). Tolking for barn - en statusrapport $\mathrm{HiO}$ rapport (Interpreting for children - a status report). Oslo: Høgskolen i Oslo.

Roy, C. (2000). Interpreting as a discourse process. New York: Oxford University Press.

Sacks, H., Schegloff, E., \& Jefferson, G. (1974). A simplest Systematics for the Organization of Turn-Taking for Conversation. Language, 50(4), 696-735.

Schick, B., Williams, K., \& Kupermintz, H. (2006). Look Who`s Left Behind: Educational Interpreters and Access to Education for Deaf and Hard-of-Hearing Students. Journal of deaf studies and deaf education, $11(1), 3-20$.

Van Leeuwen, T., \& Jewitt, C. (2001). Handbook of visual analysis. London: Sage.

Wadensjö, C. (1998). Interpreting as interaction. London: Longman.

Winston, E. (2004). Educational interpreting: How it can succeed. Washington: Gallaudet University Press. 